\title{
Effect of stabilizers on the shear strength of residual soil
}

\author{
Lamyaa Najah Snodi ${ }^{1, *}$, Yahya Atemimi ${ }^{2}$ and Fauziah binti Ahmad $^{3}$ \\ ${ }^{1}$ Civil Engineering Department, College of Engineering, Tikrit University, Tikrit, Iraq \\ ${ }^{2}$ Civil Engineering Department, College of Engineering, Babylon University, Hilla, Iraq \\ ${ }^{3}$ School of Civil Engineering, Universiti Sains Malaysia, Pulau Penang, Malaysia
}

\begin{abstract}
In this paper, chemical stabilizer was used for soil characteristics improvement. Styrene Butadiene Rubber (SBR) polymer and lime is effectively used as an inexpensive and easily applied material for soil stabilization and its response performance was evaluated. This research studied improving the engineering properties of Residual soil by mixing it with varying percentages of chemical stabilizer. An evaluation of the effectiveness and performance of SBR and Lime as a soil stabilizer was performed over a series of laboratory tests for geotechnical soil properties. Residual soil used in this study was lateritic soil. The soil was mixed with various amounts of stabilizer for polymer (SBR) $\{2.5,5,10$ and $12.5 \%\}$ and for lime $\{1.25,2.5,5$ and $10 \%\}$ by weight and then compacted at the optimum moisture content (OMC) and maximum dry unit weight (MMD). The original soil and the stabilized samples were subjected to unconfined compression test to determine their strength at different curing times (7,14 and 28 day). The results showed a reduction in the plasticity index. The results showed an increase in strength.
\end{abstract}

\section{Introduction}

In order to solve soil problems, the researchers have paid serious attention in use of a variety of chemical additives to improve the geotechnical properties. Chemical stabilizers can be classified into traditional stabilizers and non-traditional soil additives. Traditional stabilizers could be cement, cement dust [1] and lime [2]. Nontraditional stabilizers can be classified into: sulfates, salts, petroleum resins, tree resins, and polymers [3,4].

There is no study that has thoroughly investigates selecting the type of stabilizer and no clear procedure to follow these materials has been provided $[5,6]$.

Styrene Butadiene Rubber (SBR) is one example of liquid additive nontraditional stabilizer, derived from styrene and butadiene monomers [7]. Lime is hydrated high calcium as one of traditional stabilizers.

Residual soils are separated over a wide range of tropical and semi-tropical region in the world. Therefore, it is commonly used in various engineering practices [8]. A lateritic residual soil has a reddish color; this type of soil is unsuitable for use in construction practices because of its low strength or excessive volume change due to varying moisture content. In these years, the types of deserted soils have started to fall; therefore, the construction companies have turned to un-desert soil, which needs to be improved. Therefore, soil stabilization is one of the most important solutions to improve soil characteristics [9].

This study investigates the strength of residual soils to evaluate the effect of stabilizer on it.

\section{Materials and methods}

Residual soil used in this study has been collected from (USM), Penang, Malaysia.

Distributed soil samples were collected from a depth of $1.0 \mathrm{~m}$ from the ground surface and then air- dried. The soil were classified into SM, according to the Unified Soil Classification System (USCS), Table1

Table 1. Soils properties

\begin{tabular}{|c|c|}
\hline $\begin{array}{c}\text { Properties of } \\
\text { Soil }\end{array}$ & Values \\
\hline $\mathrm{G}_{\mathrm{s}}$ & 2.66 \\
\hline Color & Reddish yellow \\
\hline $\mathrm{LL} \%$ & 44 \\
\hline $\mathrm{PL} \%$ & 32 \\
\hline $\mathrm{PI} \%$ & 11.8 \\
\hline $\begin{array}{c}\% \text { finer }<0.075 \\
\mathrm{~mm}\end{array}$ & 32 \\
\hline $\mathrm{pH}$ & 4.9 \\
\hline $\begin{array}{c}\text { Organic content } \\
(\mathrm{OC}) \%\end{array}$ & 6 \\
\hline $\mathrm{MMD} \mathrm{g} / \mathrm{cm}^{3}$ & 1.85 \\
\hline OMC $\%$ & 13.7 \\
\hline
\end{tabular}

Styrene Butadiene Rubber (SBR) was obtained from the Company in Malaysia under its commercial name NBTI. Also, Lime (hydrated high calcium $\left[\mathrm{Ca}(\mathrm{OH})_{2}\right]$ ) was used. Tests were conducted on the stabilizer (polymer

* Corresponding author: dr.lamyaanajah@tu.edu.iq 
and Lime) to identify the properties such as density, shear strength, and $\mathrm{pH}[10]$ and these are reported in Table 2.

Table 2. Chemical composition of the stabilizer

\begin{tabular}{|c|c|c|c|}
\hline \multirow{2}{*}{ Test } & \multicolumn{2}{|c|}{ Property } & \multirow{2}{*}{ specification } \\
\cline { 2 - 3 } & SBR & Lime & \\
\hline PH & 5.5 & 11.8 & $\begin{array}{c}\text { BS.1377: } \\
\text { Part3:1990 }\end{array}$ \\
\hline Density & $\begin{array}{c}1.05 \\
\mathrm{~g} / \mathrm{cm}^{3}\end{array}$ & - & \\
\hline $\begin{array}{l}\text { Strength } \\
\text { of Shear }\end{array}$ & \multicolumn{2}{|l|}{ increase with time } & $\begin{array}{c}\text { ASTM - } \\
\text { D196-99 }\end{array}$ \\
\hline
\end{tabular}

The quantities of additives and curing time used in this study are listed in Table 3 . All samples were dried in oven at $\left(105-110^{\circ} \mathrm{C}\right)$ over a 24 hour period.were added as a percentage of weight, for SBR blending with distilled water at its optimum moisture content (OMC) then added to the soil. Lime was added to the soil then mixed by hand-, until it reached a uniform color. The samples were then stored in a plastic bag to maintain its moisture content. A basic property test for soil was conducted on control soil. The engineering test properties were conducted in a mixture of soils with an allowance for curing time.

Table 3. Program for Mix design

\begin{tabular}{|c|c|c|}
\hline $\begin{array}{c}\text { Soil : SBR } \\
\text { ratio }\end{array}$ & Soil : Lime ratio & $\begin{array}{c}\text { Curing time } \\
\text { (Days) }\end{array}$ \\
\hline $1: 0.025$ & $1: 0.0125$ & $7,14,28$ \\
\hline $1: 0.05$ & $1: 0.025$ & $7,14,28$ \\
\hline $1: 0.1$ & $1: 0.05$ & $7,14,28$ \\
\hline $1: 0.125$ & $1: 0.1$ & $7,14,28$ \\
\hline
\end{tabular}

A gradation test was conducted on the soil used in this experiment. Hydrometer and Wet sieving test were carried out using distilled water according to BS1377: part 2: 1990. Soil was passed through sieve $(4.75 \mathrm{~mm})$ before the test.

British standard compaction was used. Dried soil samples by oven were passed through sieve with a 4.75 mm, mixed with $0,2.5,5,10$ and $12.5 \%$ SBR and with $0,1.25,2.5,5$ and $10 \%$ Lime of dry soil were used. This test was carried out in accordance with BS 1377: part 4: 1990 [11].

The cylindrical soil specimens were having dimensions of $152 \mathrm{~mm}$ diameter and $127 \mathrm{~mm}$ height. The samples were prepared in accordance with BS 1377: part 4: 1990 clause 7.2.4. By using the machine for compaction, the load was applied with strain rate of $(1 \mathrm{~mm} / \mathrm{min})$ and a cell load of $5 \mathrm{kN}$ having steel road $(50 \mathrm{~mm})$ diameter fixed at the top of the frame of device was used to record the load applied to the sample. Moreover, a surcharge load of $50 \mathrm{~N}$ was used as recommended by BS 1377: part 4: 1990: clause 7.4.2.3, and 7.4.3.4.

UCS test was performed on cylindrical samples with a height of $76 \mathrm{~mm}$ and a diameter of $38 \mathrm{~mm}$, according to
B.S 1377: part 7: 1990: clause 7. The required weight of the soil used was calculated using equation:

$$
W_{d}=\gamma_{d \max .} \times V
$$

$W_{d}$ : dry soil weight in (gram),

$\gamma_{d \text { max. }}$ : maximum dry density $\left(\mathrm{g} / \mathrm{cm}^{3}\right)$,

$V$ : volume of mold in $\mathrm{cm}^{3}$.

The chemical stabilizers (SBR, lime) mixed with a quantity of water equal to the optimum moisture content (OMC) of the specimen which was obtained from the compaction test. The mixture was then compacted to the maximum dry density based on the Modified Proctor compaction test.

\section{Results and discussion}

\subsection{Gradation}

Figure 1 shows the gradation result for the residual soil used. The results showed the soil SM has $32 \%$ fine grain soil with $100 \%$ passing through a No.4 sieve as a silty sand soil.

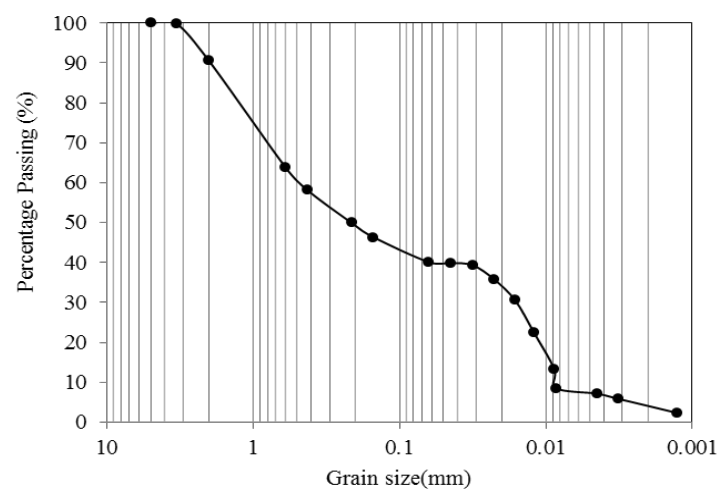

Fig. 1. Distribution curve for soil used

\subsection{Index properties}

From the plasticity chart for soil as shown in Figure 2 and Figure 3, the soil treated with SBR and Lime at different percentages exhibited a slight change in the position of all SM - (SBR , Lime) percentage mixtures and were classified as remaining at low plasticity under the A- line. Identical trends were reported by $[12,13]$. 


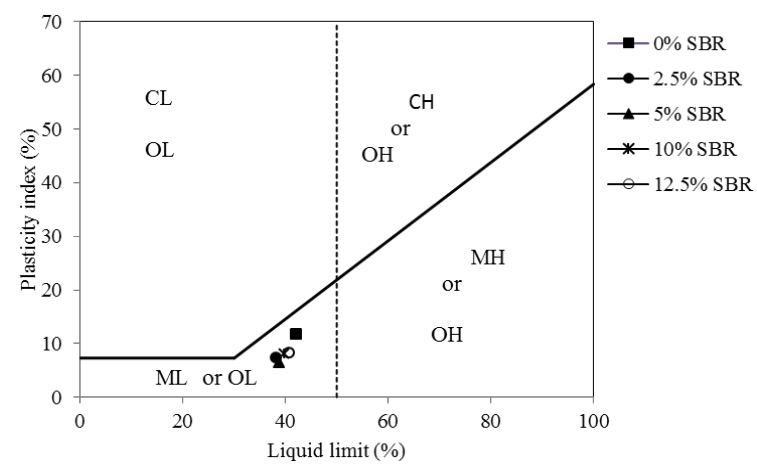

Fig. 2. Effect of SBR on consistency limit.

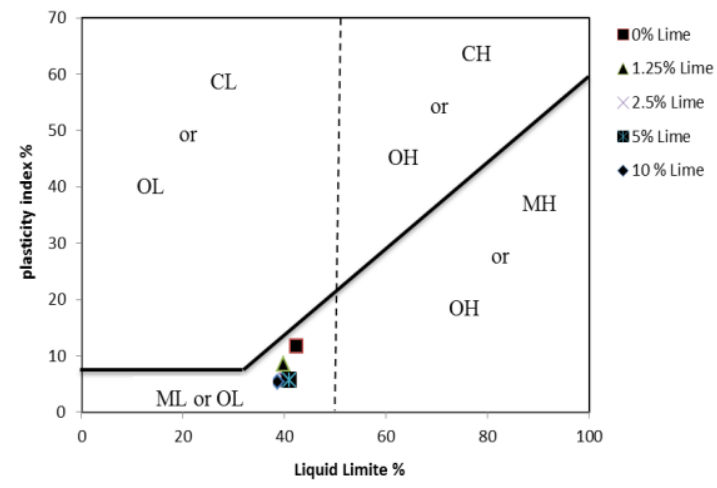

Fig. 3. Effect of lime on consistency limit.

Figure 4 and Figure 5 shows a reduction in the plasticity index a maximum reduction of $5 \%$. The soil exhibited a different behavior for SBR. Increase in the plasticity index can be attributed to the liquid stabilizer (SBR) which filled the voids of the soil. The Atterberg limits of this soil when untreated can be attributed to its mineralogical composition with respect to residual soils.

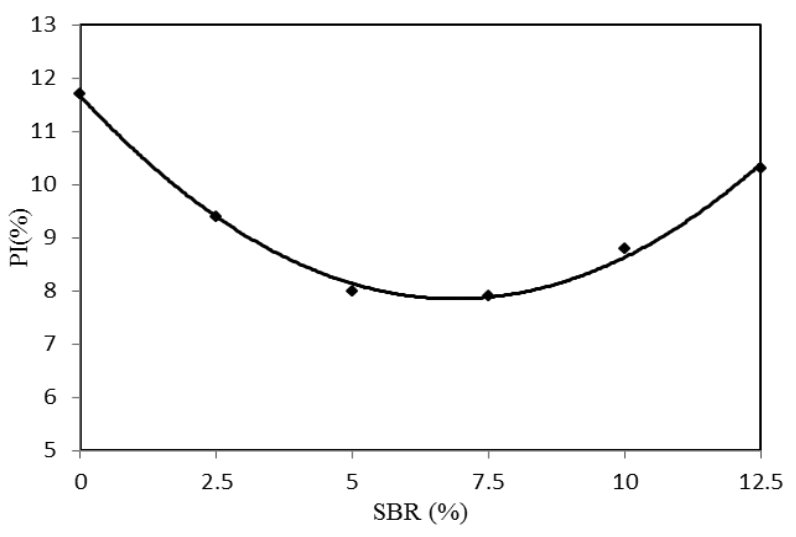

Fig. 4. Effect of SBR on PI of soil.

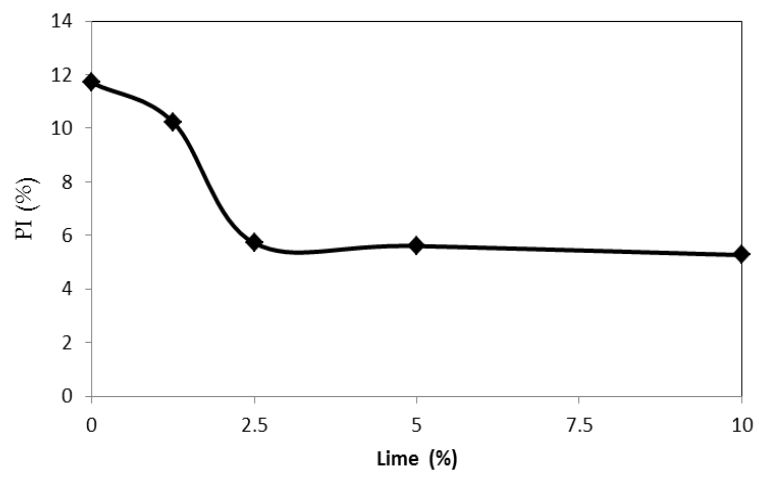

Fig. 5. Effect of lime on PI of soil.

\subsection{Compaction}

Results of the compaction test are shown in Figures 6 and Figure 7. It is shown that the soil exhibits a reduction in maximum unit weight compared to the control soil density and this decreased can be attributed to the flocculation and the agglomeration polymer effect, caused by the increase in the soil porosity. In addition, the $\mathrm{OMC}$ increased at $5 \%$ then began to reduce.. Decreasing the dry density shows it needs a low combustive energy (CE) to achieve a maximum dry density. As a result, compaction costs are reduced [14]. Similar findings have been reported by several researchers [15-17].

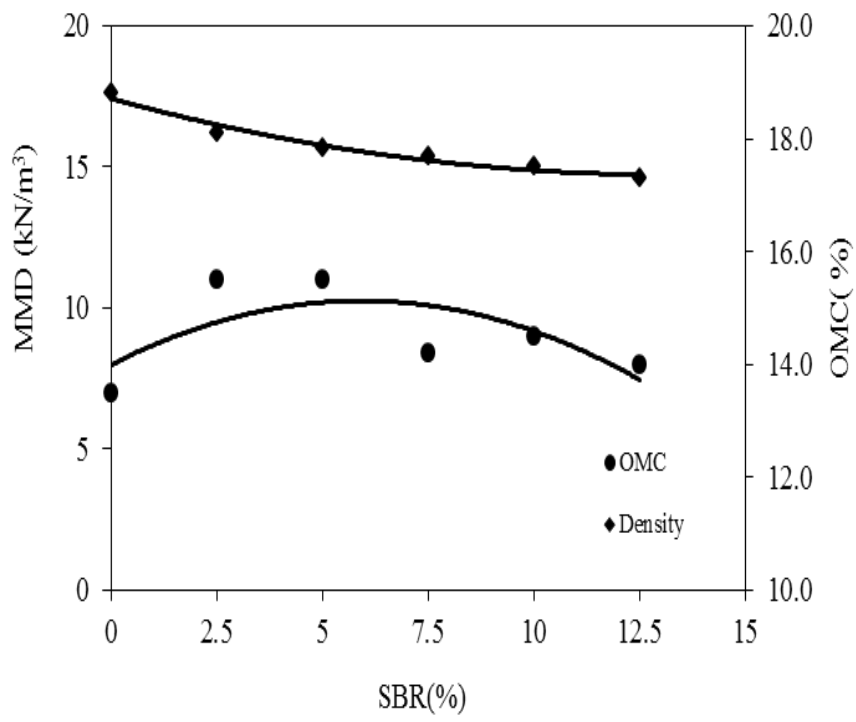

Fig. 6. Maximum unit weight and $\mathrm{OMC}$ at different SBR\%. 


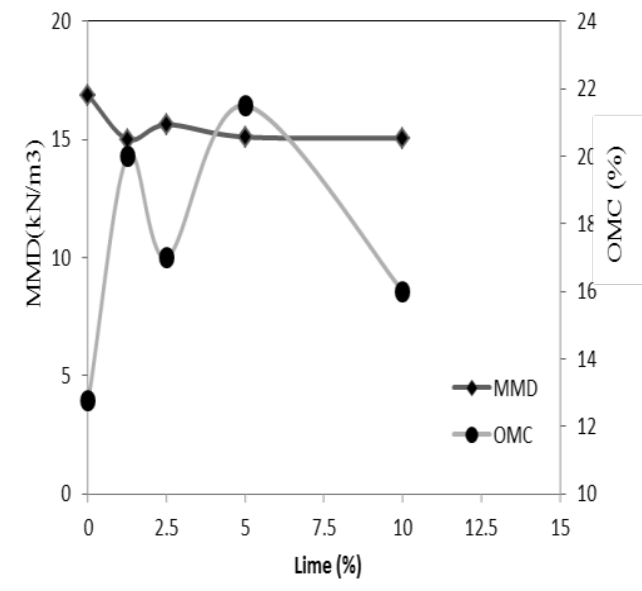

Fig. 7. Maximum unit weight and $\mathrm{OMC}$ at different Lime $\%$.

\subsection{Unconfined compression strength test results}

Figure 8 shows effect of curing time on strength at different percentages of SBR. The mixture of soil had a strength below that of the original soil during the first day after mixing and then began to increase as the curing time increased. The 5\% SBR exhibited a maximum strength when compared to all other mixtures. The strength increased in the soil at 5\% SBR after 28 days. A similar behavior trend was found trend [18].

Figure 9 shows effect of curing time on strength of soil at different percentages of lime with soil. The results showed a strength increase of 5\% Lime.

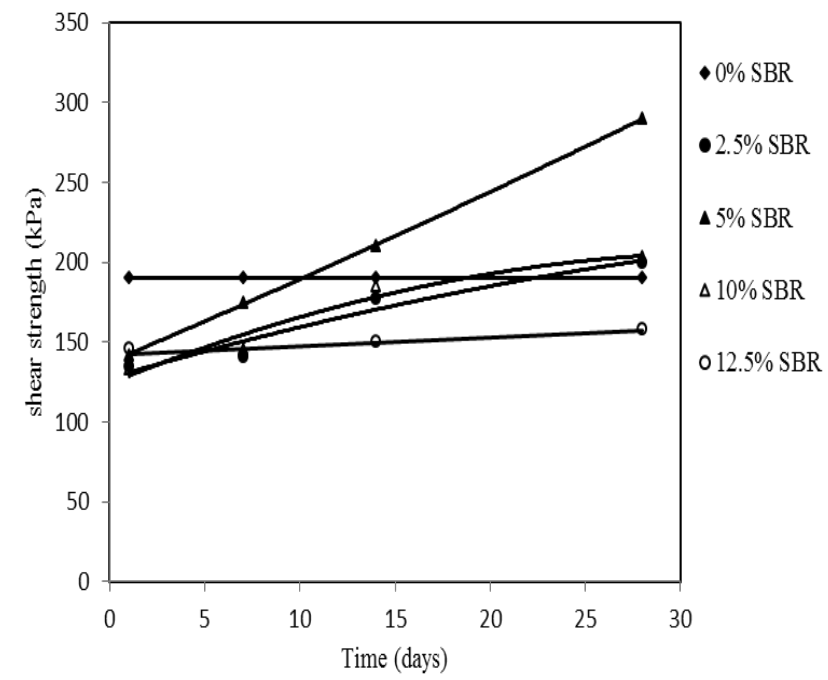

Fig. 8. Effect of curing time on strength of soil at different $\mathrm{SBR} \%$

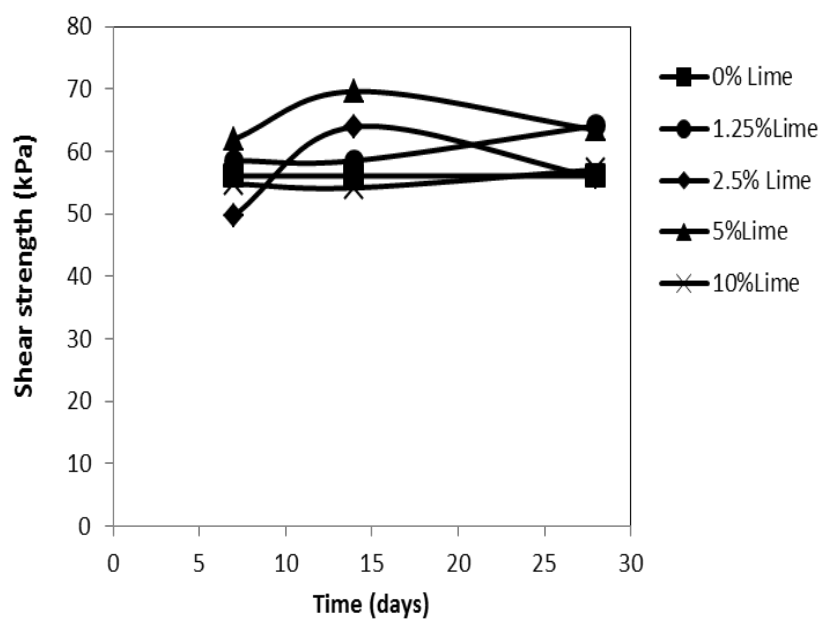

Fig. 9. Effect of curing time on strength of soil at different Lime\%

\section{Conclusions}

The following conclusions are observed based on the results :

1. The chemical stabilizers affect the plasticity index.

2. Due to the difference in densities between additives and soil we cannot depend on the compaction results.

3. The soil strength is increased.

4. Curing time had an effect on all geotechnical soil properties.

5. The soil texture affects the additives percentage.

\section{References}

1. G. Miller, S. Azad. "Influence of Soil type on Stabilization with Cement Kiln Dust". Construction and Building Materials Journal,14, 89-97(2000).

2. N. Attoh. "Lime Treatment of Laterite Soils and Gravels- Revisited" Construction and Building Materials Journal ,9, 283-287(1995).

3. S. Lahalih, N. Ahmed. "Effect of New Soil Stabilizers on the Compressive Strength of Dune Sand". Construction and Building Materials Journal, 12, 321-328(1998).

4. J.Tingle, K. Newman, S. Larson, C. Weiss, J. Rushing. "Stabilization Mechanisms of Nontraditional Additives". Transportation Reaearch Recordion : Journal of the Transportat Research Board 2, 59-67(2007).

5. S. Naeini, B. Naderinia, E. Izadi. "Unconfined Compressive Strength of Clay Soils Stabilized with Waterborn Polymer". KSCE Journal of Civil Engineering 16, 943-949(2012).

6. N. Naderi, S. Naeini. "The Influence of Polymer Inclusion and Plasticity Index on the 
Unconfined Compression Strength of Clays". 2nd International Conference on New Developments in Soil Mechanics and Geotechnical Engineering, Near East University, Nicosia, North Cyprus. (2009).

7. D. Matzen, E. Straube. "Mechanical Properties of SBR-Networks: I. Determination of Crosslink Densities by Stress-StrainMeasurements". Colloid and Polymer Science 270, 1-8(1992).

8. B. Badmus. "Plasticity and Compressibility Characteristics of Lateritic Soil from Southwestern Nigeria". Research journal of soil and water management 1,10-14(2010).

9. Y. Atemimi , F. Ahmad. "Influence of New Liquid Stabilizer on strength of Residual soils". The Iraqi Journal for Mechanical and Material Engineering, Special Volume, Babylon First International Engineering Conference, Issue (C), 436-449 (2015).

10. ASTM. Annual Book of ASTM standards. ASTM International, West Conshohocken, PA, www.astm.org. ,04-08(2005).

11. BS. Methods of Test for Soils for Civil Engineering Purposes 1377 (1990). British Standards Institution 2 park street London W1A 2BS (2000).

12. M. Muazu. "Evaluation of Plasticity and Particle Size Distribution Characteristics of Bagasse Ash on Cement Treated Lateritic Soil". Leonardo Journal of Sciences 10,137152(2007).

13. A. Olarewaju, M. Balogun, S. Akinlou. "Suitability of Eggshell Stabilized Lateritic Soil as Subgrade Material for Road Construction". EJGE 16,899-908(2011).

14. Y. Bagheri, Y. Atemimi, F. Ahmad, M. Ismail. "Soil Strength improvement by using a new compound stabilizer". Caspian Journal of Applied Sciences Research, 2 (AICCE'12 \& GIZ' 12), 84-90, (2013)

15. A. Rahman. "The Potential of Some Stabilizers for the Use of Lateritic Soil in Construction". Building and environmental Journal, 21,5761(1986).

16. S. Nayak, B. Sunil, S. Shrihari. "Hydraulic and Compaction Characteristics of leachateContaminated Lateritic Soil". Engineering Geology 94,137-144(2007).

17. M. AL-Tai, A. Mohamed Ali, B. Albdean. Improvement of Selected Parts of Basrah Governorate Soil Using Resorcinol Resin. Basra Journal of Science, 27,1- 16(2009).

18. Y. Atemimi, Y. Bagheri, F. Ahmad. "The Influence of Soil Stabilization Techniques by Styrene Butadiene Rubber on the Soil Strength". Awam International Conference on Civil Engineering (AICCE'12) Geohazard Information Zonation (GIZ'12) Park Royal Penang Resort, $28^{\text {th }}-30^{\text {th }}(2012)$. 